\title{
Procedure Elapsed Time
}

National Cancer Institute

\section{Source}

National Cancer Institute. Procedure Elapsed Time. NCI Thesaurus. Code C117536.

The interval between two procedure reference time points. 